\title{
IMPLEMENTASI HUKUM KONTRAK SEBAGAI ALTERNATIF BENEFIT SHARING DARI NILAI-NILAI TRADITIONAL KNOWLEDGE PADA TEMPE
}

\author{
Rachmat Adi Pimantoro 1
}

\begin{abstract}
The term Traditional Knowledge (traditional knowledge) is a general term that includes creative expression, information, and know-how which typically have their own characteristics and can identify social unit. In many ways, forms of knowledge not as in terms of everyday English. The special shape of the traditional knowledge of environmental knowledge (traditional knowledge environment). Related to the concept of protection of traditional knowledge ownership of Indonesian society with the use of the IPR regime was already performed previously by a very famous traditional food in all circles, namely tempe. But it is unfortunately not from the people of Indonesia, but the patent was born by companies from the United States and teresebut patents registered in the country. Seeing this reality, the real need to improve the protection of traditional knowledge, more in particular is to the makers or State Indonesian tempeh can feel commercial advantage and a greater appreciation when protected by Benefit Sharing system in tempe.
\end{abstract}

Keywords: tempe, contract law, IPR

\begin{abstract}
Abstrak
Istilah Traditional Knowledge (pengetahuan tradisional) adalah istilah umum yang mencakup ekpresi kreatif, informasi, dan know how yang secara khusus mempunyai ciri-ciri sendiri dan dapat mengidentifikasi unit sosial. Dalam Banyak cara, bentuk knowledge tidak seperti yang ada dalam istilah bahasa inggris sehari-hari. Bentu khusus dari knowledge lingkungan pengetahuan tradisional (traditional environment knowledge). Terkait dengan konsep perlindungan pengetahuan tradisional kepemilikan masyarakat Indonesia dengan penggunaan rezim HKI ternyata sudah dilakukan sebelumnya oleh makanan tradisional yang sangat terkenal disemua kalangan, yakni tempe. Namun hal tersebut sayangnya bukan dari pihak masyarakat Indonesia melainkan paten itu terlahir oleh perusahaan dari negara Amerika Serikat dan didaftarkan paten teresebut di negaranya. Melihat kenyataan demikian, sesungguhnya harus ada upaya perlindungan terhadap traditional knowledge, lebih khususnya adalah untuk para pembuat tempe atau Negara Indonesia dapat merasakan keuntungan secara komersil dan penghargaan yang lebih apabila dilindungi dengan sistem Benefit Sharing pada tempe tersebut.
\end{abstract}

\footnotetext{
${ }^{1}$ Penulis adalah Advokat pada Kantor Hukum Dewi Mulyaraharjani, Firman Gani \& Partners, Jakarta. Alamat kontak: rachmat.adi.pimantoro@gmail.com.
} 
Kata kunci: tempe, hukum kontrak, HKI

\section{Pendahuluan}

\section{Latar Belakang}

Pengetahuan tradisional merupakan permasalahan hukum yang baru yang berkembang baik di tingkat internasional maupun nasional. Pengetahuan tradisional telah muncul menjadi masalah hukum baru disebabkan belum ada instrumen hukum domestik yang mampumemberikan perlindungan hukum seara optimal terhadap pengetahuan tradisional ini, karena saat ini banyak dimanfaatkan oleh pihak-pihak yang tidak bertanggung jawab. Disamping itu, di tingkat internasional pengetahuan tradisional ini belum mempunyai peraturan yang jelas. ${ }^{2}$

Istilah Traditional Knowledge (pengetahuan tradisional) adalah istilah umum yang mencakup ekpresi kreatif, informasi, dan know how yang secara khusus mempunyai ciri-ciri sendiri dan dapat mengidentifikasi unit sosial. Dalam Banyak cara, bentuk knowledge tidak seperti yang ada dalam istilah bahasa inggris sehari-hari. Bentu khusus dari knowledge lingkungan pengetahuan tradisional (traditional environment knowledge). ${ }^{3}$

Pengetahuan tradisional mulai menjadi berkembang dari tahun ke tahun siring dengan pembaruan hukum dan kebijakan, seperti kebijakan pengembangan pertanian, keanekaragaman hayati (biological diversity), dan kekayaan intelektual (intellectual property). Masalah ini banyak menjadi diskursus di lingkungan organisasi internasional, seperti UNDP, UNESCO, dan World Bank. ${ }^{4}$

Kemudian pengertian yang dimiliki oleh masyarakat asli mengenai pengetahuan tradisional pun bervariasi. ${ }^{5}$

1) Tradisional knowledge merupakan hasil pemikiran praktis yang didasarkan atas pengajaran dan pengalaman dari generasi ke generasi.

2 WIPO Secretariat, Intergovernmental Committee on Intellectual Property and Genetic Resources, Traditional Knowledge and Folklore (IGC), Sampai dengan saat ini tercatat sudah melakukan sesi ke 28 pada bulan July 2014 belum menghasilkan peraturan yang dapat di implementasikan kepada negara-negara anggota WIPO.

${ }^{3}$ Center for Inovation Law and Policy, Traditional Knowledge Reasearch Guide, dalam <http://www.innovationlaw.org/lawforum/pages/rg_traditional_knowledge.htm>, diakses pada tanggal 23 November 2015.

${ }^{4}$ Ibid.

5 Patricia A L Cochran, “What is Traditional Knowledge?, <http://www.nativescience.org/ html/traditional_knowledge.html>, diakses pada tanggal 23 November 2015. 
2) Tradisional knowledge merupakah pengetahuan daerah perkampungan

3) Tradisional knwoledge tidak dapat dipisahkan dari masyarakat pemegangnya, meliputi kesehatan, spiritual, budaya dan bahasa dari masyarakat pemegang. Hal ini merupakan way of life.Tradisional knowledge lahir dari semangat untuk bertahan.

4) Tradisional knowledge memberikan kredibilitas pada masyarakat pemegannya.

Dari pemahaman terebut, traditional knowledge dapat diartikan sebagai pengetahuan tradisional yang dimiliki oleh masyarakat daerah atau tradisi yang sifatnya turun-temurun. Pengetahuan tradisional itu sendiri ruang lingkupnya sangat luas, dapat meliputi bidang seni, tumbuhan, arsitektur, dan lain sebagainya.

Saat ini masalahg traditional knowledge dapat dibagi ke dalam dua permasalahan utama, yakni: ${ }^{6}$

1) Perlindungan yang mempertahanan traditional knowledge atau ketentuan yang menamin itu tidak akan sukses di peroleh oleh Hak Kekayaan Intelektual melalui ketentuan traditional knowledge yang konvensional.

2) Perlindungan yang mempertahankan traditional knowledge akan suskses dengan menggunakan mekanisme hukum tradisional (existing legal mechanisms) seperti kontrak, pembatasan akses (acces restriction), dan Hak Kekayaan Intelektual.

Berdasarkan dua permasalahan ini, maka dapat disimpulkan bahwa perlindungan traditional knowledge di satu sisi jika menggunakan ketentuan tradisional tidak dapat menjamin kesuksesan dalam melindungi traditional knowledge, namun di sisi lain perlindungan traditional knowledge dapat dilakukan melalui upaya melindungi pengetahuan tradisional masyarakat dengan menggunakan pendekatan ketentuan konvensional, yakni dengan penggunaan rezim HKI yang kini berlaku.

Terkait dengan konsep perlindungan pengetahuan tradisional kepemilikan masyarakat Indonesia dengan penggunaan rezim HKI ternyata sudah dilakukan sebelumnya oleh makanan tradisional yang sangat terkenal disemua kalangan, yakni tempe. Namun hal tersebut sayangnya bukan dari pihak masyarakat Indonesia melainkan paten itu terlahir oleh perusahaan dari negara Amerika Serikat dan didaftarkan paten teresebut di negaranya. ${ }^{7}$

6 WIPO, Intellectual Property, Genetic Resources, Traditional Knowledge, and Folklore, <http://www.wipo.org/globalissues/tk/back-ground/index.html>, diakses pada tanggal 23 November 2015.

${ }^{7}$ United States Patent Office, <http://patft.uspto.gov/>, di akses pada tangal 23 November 2015. Tercatat di dalamnya dengan nomor paten US3681085A pada tanggal 27 April 1970 mengenai "food 
Perlu digaris bawahi rezim hak paten pada HKI perlindungannya adalah teritorial dan tidak berlaku perlindungan tersebut di suatu negara apabila tidak dilakukan pendaftaran terlebih dahulu di negara-negara tujuan untuk dilangsungkan perdagangan atas produk yang invensinya dilindungi hak paten setempat. Nyatanya terhadap lisensi hak paten tempe yang terdaftar di United States Patent and Trademark Office memiliki priority date yang mana berarti sang inventor juga mendaftarkan ke negara-negara tujuan bisnis penjualan tempe nya. ${ }^{8}$

Adalah suatu hal yang lumrah melihat kejadian ironis tersebutbila kita menarik kesimpulan dengan mengambil sudut pandang perbandingan perkembangan hukum HKI yang ada di Indonesia. Undang-Undang Paten Indonesia bermula pada No. 6 tahun 1989 berlaku pada tanggal 1 Agustus 1991, sampai dengan berlakunya Undang-Undang tentang Paten No. 13 tahun 1997 tentang perubahan Undang-Undang Paten No. 6 tahun 1989 (berlaku 7 Mei 1997), yang kemudian disempurnakan dengan Undang-Undang Nomor 14 tahun 2001 tentang Paten (berlaku 1 Agustus 2001). Dan karena perkembangan yang lambat inilah negara ini "kecolongan" atas yang seharusnya dapat dilindungi oleh hak paten.

Lebih ironisnya lagi adalah, tempe adalah suatu makanan yang tidak terbantahkan bagian dari pengetahuan tradisional masyarakat Indonesia, dengan adanya perlindungan hak paten dari Amerika Serikat dan pada saat melakukan bisnisnya yang sudah pasti akan berlangsung lamasang inventor akan terus mendapatkan penghargaan dan keuntungan.Tidak mengherankan apabila terjadi suatu hal yang disebut dengan identity crisis karenanya masyarakat modern akan lebih mengenal tempe adalah hasil invensi masyarakat Amerika Serikat melainkan hasil kebudayaan Indonesia.

Melihat kenyataan demikian, sesungguhnya harus ada upaya perlindungan terhadap traditional knowledge, lebih khususnya adalah untuk para pembuat tempe atau Negara Indonesia dapat merasakan keuntungan secara komersil dan penghargaan yang lebih apabila dilindungi dengan sistem Benefit Sharing pada tempe tersebut. Perlindungan dalam konteks jangka pendek dapat kiranya digunakan pendeketan konvensional, namun dalam konteks jangka panjang akan sangat tepat apabila Rancangan Undang-Undang TENTANGPENGETAHUAN TRADISIONAL DAN EKSPRESI BUDAYA TRADISIONAL segera di sahkan karena perlindungan terhadapnya akan secara tegas dan jelas serta dapat dilakukan secara optimal.

product containing tempeh" yang di invensikan serta di daftarkan oleh Gyorgy Paul dan nomor paten US3228773A pada tanggal 13 Desember 1962 mengenai "Methods for producing tempeh" yang di invensikan serta di daftarkan oleh Hesseltine Clifford W dan Martinelli Jr Alcides. 


\section{Pokok Permasalahan}

Berdasarkan uraian yang telah di paparkan sebelumnya penulis dengan ini merumuskan masalah yang akan dibahas dalah penulisan ini adalah sebagai berikut:

1) Apakah perlindungan dari hak paten dapat melindungi pengetahuan tradisional pada makanan tempe?

2) Apakah Hukum Kontrak dapat dijadikan sebagai alternatif Benefit Sharing?

\section{Metode Penulisan}

Dalam memecahkan permasalahan yang dikemukakan sebelumnya, penulis karya ilmiah ini dalam segi metodologi empiris dengan pendekatan konsep (conceptual approach) dan analisa (analytical approach) serta dengan gaya penulisan deduktif perskriptif serta informasi dilakukan melalui penelitian kepustakaan (library research).

\section{Pembahasan}

\section{Hak Paten Tempe}

\section{a. Hak Kekayaan Intelektual: Hak Paten}

Tumbuhnya organisasi-organisasi internasional, khususnya di bawah naungan Perserikatan Bangsa-Bangsa telah menyediakan satu forum untuk mendiskusikan tuntutan-tuntutan serupa itu, yaitu World Intellectual Property Organisation (WIPO) yang diantaranya mengatur Paris Convention for the Protection of Industrial Property, Berne Convention for the Protection of Literary and Artistic Works dan Patent Cooperation Treaty. WIPO adalah salah satu organisasi di bawah naungan Perserikatan Bangsa-Bangsa; United Nations Educational, Scientific and Cultural Organization (UNESCO) mengatur Universal Copyright Convention dan berurusan dengan masalah-masalah ha cipta lainnya yang berperan untuk United Nations Conference on Trade and Developement (UNCTAD). ${ }^{9}$

9 W.R. Cornish, F.B.A. "Intellectual Property: Patents, Copyrights, Trademark and Allied Rights”, (London: Sweet \& Maxwell, 1989), hal. 11. 
Salah satu sisi HKI yang tidak dapat dielakan, terutama dewasa ini adalah semakin eratnya kaitan dan pengaruh HKI dalam perdangan internasional. HKI menjadi semakin penting mengingat perannya yang begitu besar bagi kehidupan industri dan perdagangan internasional. Dengan alasan apapun, pemilik HKI telah semakin menyadari dan memahami tentang arti peran dan pentingnya perlindungan HKI sebagai aset dan komoditi yang diperdagangkan.

Tujuan yang sesungguhnya dari HKI adalah memberi perlindungan bagi perusahaan-perusahaan pemili HKI terhadap perusahaan-perusahaan pesaing yang akan menjual langsung produkproduk atau asa sebagai persaingan. Dalam perdagangan internasional, bagaimanapun HKI telah memilii arti yang sangat penting. Pada banyak kasus, dengan mengadopsi aturan-aturan hukum yang memadai, perindahan produk-produk yang diproduksi oleh satu organisasi perusanaa atau perusahaan gabungan dari satu wilayah ke wilayah lain dapat dicegah; hambatan terhadap hak-hak pribadi dapat diberlauan terhadap impor atau ekspor, yang sama efetifnya terhadap embargo atau tarif yang ditentuan oleh suatu negara.

Menurut Cita Citrawinda, terdapat beberapa pandangan mengenai HKI, di satu pihak HKI pada prinsipnya dipandang sebagai hak ekonomi atau komersial, dan di pihak lain HKI dipandang sama dengan hak politik atau hak asasi manusia. Pernyataan universal mengenai Hak Asasi Manusia memiliki difinisi yang lebih luas dengan mengakui adanya "hak untuk melindungi kepentingan moral dan material yang dihasilan dari arya ilmiah, karya sastra atau seni oleh penciptanya", diimbangi dengan "hak...untuk berbagi dalam kemauan ilmiah dengan euntungan yang dihasilkannya". Isu rusial yang timbul adalah bagaimana menyatuan kepentingan umum untuk mengakses pengetahuan baru dengan hasil dari pengetahuan yang baru dan kepentingan umum dalam menstimulasikan invensi dan kreasi yang menghasilkan pengetahuan serta produk-produk baru dimana emajuan materi dan budaya saling memiliki ketergantungan. Kesulitannya adalah bahwa sistem HI berusaha mencapai pemahaman ini dengan memberikan hak probadi dan keuntungan materi pribadi. Dengan demikian, hak untuk memperoleh perlindungan bagi "kepentingan moral dan epentingan material" dari "pencipta" tidak mungkin terlepas dari hak kepentingan material pribadi yang dihasilkan oleh perlindungan secam ini. Keuntungan pribadi bagi "pencipta" atau "inventor" fiperoleh dari biaya yang dikluarkan oleh konsumen dan apabila konsumen adalah orang yang tidak mampu, hal ini dapat bertentangan dengan hak dasar manusia, misalnya untuk hidup. ${ }^{10}$

\footnotetext{
${ }^{10}$ Priapantja, Cita Citrawinda, “Hak Kekayaan Intelektual: Tantangan Masa Depan”, (Depok: Badan Penerbit Fakultas Hukum Universitas Indonesia 2003), hal. 7.
} 
Sebagaimana pendapat yang dikemukakan oleh Robert $\mathrm{M}$. Shrewood, bahwa sistem HKI harus merupakan bagian dari infrastruktur, ${ }^{11}$ sebagai berikut:

Although largely invisible, an intellectual property system which protect innovation and creative expression may be viewed as a helpful precondition to creating and using new technology which boots economic growth and aids development. From this point of view, the intellectual property protection system may be considered as a valuable part of a country's infrastructure.

The concept of infrastructure has proven useful in examining economic developement. Roads, irrigation, sewers, scools, water supply, health care and electrical systems are among the precondition thought beneficial for development. Creation of infrastructure is accorded priority because of this.

Terkait dengan paten dari sisi substansi tentu akan sangat dipengaruhi dengan kajian-kajian yang sifatnya normatif. Hal ini sejalan dengan konsep substansi hukum itu sendiri. ${ }^{12}$ Menurut ketentuan Pasal 1 ayat (1) Undang-Undang Nomor 14 tahun 2001 tentang Paten (UU Paten) didefinisikan sebagai berikut:

Hak eksklusif yang diberikan oleh negara kepada inventor atas hasil invensinya di bidang tenologi, yang untuk selama waktu tertentu melaksakana sendiri invensinya tersebut atau memberikan persetujuannya kepada pihak lain untuk melaksanakannya

Dari pengertian yang telah diberikan oleh UU Paten, maka dapat ditarik beberapa unsur yang disebut dengan paten, yakni Pertama, paten adalah hak eksklusif, artinya paten sebagai hak kebendaan yang sifatnya tidak berwujud (intangable assets) merupakan hak yang dinmonopoli/khusus. Monopoli disini berarti tidak semua orang dapat mempergunakan atau melaksanakan invensi tersebut tanda ada izin dari si pegang paten; Kedua, Paten diberikan oleh negara kepada inventor, artinya untuk mendapatkan paten seorang inventor diwajibkan untuk mengajukan pendaftaran paten, jika hal ini telah dipenuhi baik dari sisi substatntif maupun administratif si inventor akan diberikan hak eksklusif tersebut oleh negara paten hanya

\footnotetext{
${ }^{11}$ Robert M. Sherwood, "Intellectual Property and Economic Development", (Boulder, San Fransisco Oxford Westview Press Inc., 1990), hal. 6.

${ }^{12}$ Lawrence M. Friedmen, “The legal System A Social Science Perspective”, (New York: Russel Sage Foundation 1975), hal. 11-16.
} 
dikhususkanpada bidang teknologi, di luar bidang teknologi tidak dapat dimintakan paten; Ketiga, paten memberikan atau untuk memberikan anga waktu tertentu untuk melaksanaan invensi tersebut atau untuk memberikan persetuuan kepada pihak lain untuk melasanakan invensi, artinya bagi inventor yang mendapatkan paten dienaan suatu ewaiban untu melaksanaan sendiri invensinya atau dapat juga memberikan izin pada piha lain yang ingin melaksanakan invensinya.

Pengertian paten ini sealan pula dengenpengertian paten yang diberian oleh WIPO sebagai badan internasional Perserikatan Bangsa-Bangsa yang mendefinisikan bahwa paten adalah: ${ }^{13}$

A patent a legally eforceable right granted by virtue od a law to a person to exclude, for a limited time, others from certain acts in relation to describe new invention, the privilege is granted by a government authority as a matter of right to the person who is entitled to apply for it and who fulfils the prescribed condition.

UU Paten selain memberikan pengertian paten juga menentukan beberapa persyaratan suatu invensi yang dapat diberian paten.Beberapa syarat yang dimasud adalah: 1) ada unsur ebaruan (novelty), artinya suatu invensi dianggap baru ia tanggal penerimaan, invensi tersebut tidak sama dengan tenologi yang diungkapkan sebelumnya. Teknologi yang diungkap sebelumnya adalah teknologi dalam suatu tulisan, uraian lisan atau melalui peragaan, atau dengan cara lain yang memungkinkan seorang ahli untuk melaksanakan invensi tersebut sebelum tanggal penerimaan atau tanggal prioritas.

Teknologi yang diungkap sebelumnya mencakup dokumen permohonan yang diajukan di Indonesia yang dipublikasikan pada atau setelah tanggal penerimaan yang pemeriksaan substantifnya sedang dilakukan, tetapi tanggal penerimaan tersebut lebihawal daripada tanggal penerimaan atau tanggal prioritas permohonan, 2) mengandung langah inventif (Inventif step). Suatu invensi mengandung langkah inventif jika invensi tersebut bagi seseorang yang mempunyai keahlian tertentu di bidang teknik merupakan hal yang tidak dapat diduga sebelumnya. Penilaian bahwa suatu invesi merupaan hal yang tidak dapat diduga sebelumnya baru dilauan dengan memperhatikan keahlian yang ada pada saat permohonan diaukan atau yang telah ada pada saat diaukan permohonan pertama dalam hal permohonan itu diajukan dengan hak prioritas, 3) dapat diterapkan dalam industri (industri applicable)). Suatu Invensi dapat diterapan dalam industri jika invensi tersebut dapa dilaksanakan dalam industri.

${ }^{13}$ Abdulkadir Muhammad, "Kajian Hukum Ekonomi Hak Kekayaan Intelektual”, (Bandung: Citra Aditya Bakti, 2001), hal. 129. 
Inilah kiranya tiga syarat yang harus dipenuhi oleh para inventor di Indonesia maupun di luar negeri, ia menghendaki invensi merea dalam bidang teknologi dapat dipatenan. Dari tiga syarat yang telah dijabarkan sebelumnya, sesungguhnya syarat yang cukup berat bagi inventor dalam memenuhi syarat invensi yang dapat dipatenkan biasanya terletak pada invensi tersebut dapat diterapkan dalam industri. $^{14}$

Apabila invensi dari inventor dapat dipatenkan, maka selanjutnya invensi dapat didaftarkan ke Kantor Direktoran Jenderal HKI. Konsep pendaftaran ini sesuai dengan prinsip first to file principle., Menurut prinsip ini bahwa paten akan dilindungi terhadap pendaftar pertama. Kebalikan dari first to invent principle, yakni inventor yang pertama melakukan invensi akan dilindungi oleh hukum paten.

Dalam proses pendaftaran apabila syarat substantif di atas dan syarat administratif telah dipenuhi, maka pihak yang mengajukan permohonan paten akan mendapatkan sertifikat paten sebagai bukti kepemilikan atas ha. Paten Indonesia memberikan ketentuan bahwa dalam epemilikan hak ini deberikan janmgka waktunya. Jangka waktu yang diberikan terhadap paten dibedakan antara paten dan paten sederhana. Untuk paten jangka waktu perlindungannya selama 20 tahun seak tanggal penerimaan (filing date) dan tidak dapat diperpanjang lagi, sedangkan untuk paten sederhana jangka waktu perlindungannya 10 tahun sejak tanggal penerimaan (filling date) dan tidak dapat diperpanjang lagi. Hal tersebut akan dilindungi oleh UU Paten.

Paten sebagai hak kebendaan juga dapat beralih atau dialihkan baik seluruhnya atau sebagian. Beberapa meanisme yang dapat ditempuh dalam erangka pengalihan ini, di antaranya pewarisan, hibah, wasiat, peranjian tertulis atau sebabg lain yang dibenarkan oleh peraturan perundang-undangan, Dengan adanya mekanisme ini, berarti yang dapat berhak terpaten tidak saa pihak yang melakukan invensi, namun juga dapat dimiliki oleh pihak yang menerima pengalihan.

\section{b. Paten Dalam Melindungi Pengetahuan Tradisional Makanan Tempe}

Dari apa yang telah di paparkan sebelumnya dengan pemberlakuan paten, khususnya dipandang dari sudut ketaatan umum terhadap Persetujuan TRIPs dengan tetap memperhatikan bahwa tiap-tiap bagian negara, masing-masing memiliki nilai historis yang

${ }^{14}$ Budi Agus Riswandi, M. Syamsudin, "Hak Kekayaan intelektual dan Budaya Hukum", (Jakarta: Raja Grafindo Persada, tt), hal. 127. 
unik, kebudayaan, sistem politik dan tingkat kemjuan ekonomi yang berbeda sebenarnya dapat dilakukan. Meskipun penerimaan umum dari Persetujuan TRIPs dan globalisasi memberi tekanan pada negara-negara non-Barat untuk mengadopsi sistem HKI yang sebenarnya berasal dari kebudayaan barat.

Menurut Agus Sardjono hal demikian itu terjadi karena dalam perdagangan internasional, khususmya yang berkenan dengan aspek HKI, Indonesia berada di bawah tekanan negara-negara maju karena harus melaksanakan TRIPs sebagai salah satu kesepakatan di dalam rezim WTO. Namun di sisi lain negara-negara maju enggan untuk mempertimbangkan kekayaan intelektual masyarakat lokal dalam bentuk pengetahuan tradisional. Ketentuan-ketentuan yang dibangun di dalam kesepakatan GATT Uruguay Round, khususnya menyangkut perdagangan dunia yang mengandung aspek HKI, belum atau bahkan tidak mempertimbahkan kepentingan penduduk atau masyarakat yang hidup di wilayah-wilayah negara berkembang. Hal ini bisa dipahami mengingat sponsor utama TRIPs adalah negara-negara maju, yang telah menikmati keuntungan dari akses yang terbuka atas sumber daya yang melimpah di kawasan negaranegara berkembang. ${ }^{15}$

Hal tersebut dapat dilihat pada contoh yang telah dipaparkan sebelumnyamengenai paten nomor paten US3681085A nomor paten US3228773A pada USPTO terhadap pengetahuan tradisional pada makanan tempe. Sudah pasti dalam melakukan bisnisnya sang inventor tersebut akan terus mendapatkan penghargaan atas invensinya dan keuntungan secara ekonomi, melainkan masyarakat lokal yang seharusnya mendapat penghargaa dan invensinya tersebut karenanya itu adalah bagian dari pengetahuan tradisionalnya. Ketidak adilan ini terjadi karena negara-negara maju menerapkan standar ganda dalam soal perlindungan hak. Di satu sisi, negaranegara maju sangat menjunjung tinggi hak-hak individual warga negaranya dalam soal yang terkait dengan perlindungan hak kekayaan intelektual. Pada sisi lain, mereka tidak nmengakui hak masyarakat di negara-negara berkembang atas kreasi intelektual mereka berupa pengatahuan tradisional.

Meskipun dari sisi aspek kekayaan intelektual pengetahuan tradisional masyarakat lokal terhadap makanan tempe telah di diskriminasi dengan peraturan-peraturan HKI yang terkait dan adanya hak paten yang terdaftar di negara lain secara resmi dan nyata, namun pengakuan pengetahuan tradisional makanan tempe sebenarnya juga diakui oleh negara barat. ${ }^{16}$ Berikut kutipan dari informasi tersebut:

${ }^{15}$ Agus Sardjono, "Hak Kekayaan Intelektual dan Pengetahuan Tradisional", (Bandung: PT. Alumni, tt), hal. 4. 
Tempeh (pronounced TEM-pay) is an Indonesian word referring collectively to a variety of fermented foods (typically tender-cooked legumes) bound together by a dense mycelium of fragrant white Rhizopus mold into compact cakes (Ko and Hesseltine 1979). The most popular of these is soy tempeh, and hereafter we will use the term "tempeh" to refer to soy tempeh, unless otherwise noted. In the West tempeh is usually sold in cakes 6 by 8 by $3 / 4$ inch thick $(15 \times 20 \times 2 \mathrm{~cm})$. These are sliced then served fried, baked, or steamed. When fried, tempeh's flavor and texture are meaty, resembling those of southern fried chicken or fish sticks. Before cooking, soy tempeh contains $19.5 \%$ protein, compared with $17.9 \%$ for hamburger and $21 \%$ for chicken, on average.

To make tempeh, cooked and dehulled soybean cotyledons (which may be lightly acidified with a traditional lactic acid prefermentation or, nowadays, with lactic acid or vinegar) are well drained then inoculated with spores of Rhizopus oligosporus mold, packed into perforated containers (polyethylene bags or banana leaves, holding about 8 ounces) and incubated at $30-31 * C(86-88 * F)$ for about 24 hours, until the beans are bound together tightly by the mycelium. The tempeh is then ready to sell or to cook.

Tempeh is unique among major traditional soyfoods in that it is the only one that did not originate in China or Japan. It originated in today's Indonesia, almost certainly in Central or East Java, almost certainly prior to 1800, and perhaps as long ago as a thousand years or more. Tempeh is also distinctive in that less is known about its origins and early history than about those of any other soyfood.

Dapat disimpulkan dari kutipan sebelumnya meskipun pada nyatanya pengetahuan tradisional makanan tempe diakui oleh Amerika Serikat, namun terkait dengan standar ganda yang dijelaskan sebelumnya, mereka membelokan fakta atas adanya hakhak komunal dari tempe tersebut.

Paten sudah tentu dapat diterapkan di dalam tempe, namun kelemahannya adalah tidak ada suatu sistem kumpulan data yang lengkap mengenai invensi yang sudah ada sebelumnya (prior art), sehingga dengan tidak tersedianya database tadi ahak menyulitkan

${ }^{16}$ Soyinfo Center, <http://www.soyinfocenter.com/HSS/tempeh1.php>, diakses pada tanggal 5 Desember 2015. Web tersebut memiliki tujuan menjadi pusat informasi makanan yang berasal dari kedelai di USA yang komprehensif. 
juga dalam proses membandingkan suatu invensi yang akan dikategorikan memiliki kebaruan, di mana kebaruan ini marupakan syarat mutlak bagi suatu invensi yang akan dipatenkan. ${ }^{17}$

Agus Sardjono pun berpendapat dalam pengimplemetasian paten terhadap pengetahuan tradisional tidak relevan karenanya pihak-pihak yang ingin memperoleh perlindungan paten harus melakukan langah-langkah tertentu yang membutuhkan keahlian dan emampuan tertentu pula. Langkah itu dimulai dari penelitian untuk menghasilkan suatu penemuan (invention), penyusunan dokumen paten berupa klain dan spesifikasi paten, pengauan permohonan perlindungan ke Kantor Paten dan seterusnya sampai dapat hak yang dimaksud. Rezim tersebut akan sulit digunakan oleh masyarakat lokal yang sederhana dan tidak terbiasa dengan tradisi tulisan, sedangkan paten menghendaki suatu tindakan yang relatif rumit dan tidak sederhana. $^{18}$

\section{c. Hukum Kontrak Sebagai Alternatif Benefit Sharing Pengetahuan Tradisional Tempe}

Setealah pembahasan pada bab sebelumnya mengenai kelemahan paten dalam melindungi pengetahuan tradisional pada makanan tempe, hukum kontrak merupakan salah satu hukum alternatif yang perlu dipertimbangkan oleh Pemerintah sebagai sarana perlindungan. Rubin memberikan landasan argumen sebelum menawarkan alternatif "kontrak" sebagai salah satu cara melindungi pengetahuan tradisional, berikut kutipannya ${ }^{19}$ :

In and around the remainingcenters of high biodiversity are also the pooriest communities in the world. These communities -especially those of tribal peaoples- have never shared in the bounties of the land. The best way to liberate these communities from the vicious cycle of poverty is through empowerment -the control of their own natural resources, and access to information and technology. To support the advocacy of these issues is to support the cause of biodiversity conservation

Penguatan (empowerment) posisi masyarakat tradisional untuk memperoleh manfaat ekonomis dari pemanfaatansumber daya hayati dilingkungannya dapat dilakuan melalui mekanisme kontrak.

${ }^{17}$ Budi Agus Riswandi, M. Syamsudin, "Hak Kekayaan intelektual dan Budaya Hukum”, (Jakarta: Raja Grafindo Persada, tt), hal. 130.

${ }^{18}$ Agus Sardjono, Op. Cit., hal. 178.

19 Steven M. Rubin \& Stanwood C. Fish, Biodiversity Prospecting:Using Innovative Contractual Provisions to Foster Ethnobotanical Knowledge, Technology, and Conservation, "Colorado Journal of International and Environmental Law and Policy", (Vol.5, 1994), hal. 26. 
Artinya, pihak luar yang ingin memanfaatkan pengetahuan tradisional dan bahan atau sumber daya yang terdapat di tengah masyarakat itu harus terlebih dahulu mendapat persetujuan dari masyarakat yang bersangkutan atau dalam hal tidak ada yang dapat mewakili masyaraat, persetujuan dapat diberikan oleh Pemerintah. Persetujuan itu dapat diwujudkan melalui perjanjian (kontrak). Hal ini juga di amanatkan dalam Pasal 8(j) Convention Biological Diversity (CBD) agar Pemerintah masing-masing negara peserta berupaya meningkatkan keterlibatan masyarakat (pemilik pengetahuan tradisional) dalam rangka pembagian manfaat (benefit sharing) atas penggunaan (utilization) pengetahuan tradisional mereka.

Rubin pun juga mengusulkan agar di dalam bioprospecting contract sekurang-kurangnya memuat access, sample supply, screening, inventions, licensing, compensation, and conservation. ${ }^{20}$ Pengaturan mengenai access akan memperjelas, species dan informasi apa saa yang akan diberikan kepada pihak yang akan memanfaatkan sumber daya hayati yang bersangkutan untuk diteliti dan dimanfaatkan. Sehubungan dengan hal ini, Pemerintah setempat dapat memberlakukan undang-undang berkenan dengan akses terhadap sumber daya genetik, yang nantinya akan menjadi acuan bagi kontrak-kontrak dengan pihak asing yang ingin memanfaatkan sumber daya genetik di negara yang bersangkutan.

Agus Sardjono mengemukakan pendapatnya terhadap implementasi kontrak sebagai bentuk perlindungan. Pertama, kontrak tersebut harus memuat ketentuan yang menegaskan bahwa informasi mengenai pemanfaatan sumber daya hayati oleh masyarakat yang bersangkutan akan digunakan hanya untuk maksud dan tujuan yang telah ditetapkan oleh prospector atau collector yang bersangkutan. Kedua, kontrak harus memuat tata cara atau prosedur yang digunakan untuk mendapatkan persetujuan (informed consent) dari para dukun atau masyarakat yang bersangkutan. Pentingnya informed consent ini menurutnya karena tidak tertutup kemungkinan sumber daya genetik yang dimaksud justru sanmgant dibutuhkan dan dimanfaatkan sendiri oleh masarakat yang bersangkutan dan bila prospector berniat untuk mempatenkan hasil temuannya yang berasal dari pengetahuan tradisional masyarakat, hal ini harus disebutkan dengan tegas di dalam kontrak. Hal ini ada kaitannya dengan pembagian manfaat (benefit sharing) atas paten tersebut. Masalahnya adalagh, bahwa anggota masarakat biasanya tidak memahami konsep paten. Oleh karena itu, kepada mereka harus dijelaskan terlebih dahulu seluk beluk mengenai paten. ${ }^{21}$

\footnotetext{
${ }^{20}$ Ibid., hal. 37.
} 
Terkait dengan ini WIPO telah memberikan contoh provisions ang dapat digunakan dalam penyusunan draft kontrak antara provider (yang dalam hal ini Pemerintah Indonesia) dengan bioprospector, sebagai berikut: ${ }^{2}$

(1) Para pihak. Dalam hal ini Pemerintah Indonesia, baik pusat maupun dareah, bergantung kepada kebijakan yang akan ditetapkan kemudian, adalah provider, Sedangkan, perusahaanperusahaan atau lembaga penelitian atau lembaga lain yang akan melakukan bioprospectingadalah pihak lainnya, yang oleh WIPO disebut recipient.

(2) Ruang lingkup yang diperjanjikan (scope of contract). Mengenai ruang lingkup ini tentu sajasangat bergantung kepada kebutuhan atau apa yang ingin dilaukan dengan kontrak yang bersangkutan., Dalam Sistetm Kitab Undang-Undang Hukum Perdata, ruang lingup ini adalah merupakan "hal tertentu" yang diperjanjikan. ${ }^{23}$ Dengan demikian, ruang lingkup adalah sesuatu yang harus dapat ditentukan dengan jelas dan dapat dilaksanakan oleh kedua belah pihak.

Asas maupun prinsip dasar (fundamental principles) yang dikenal dalam hukum perdagangan internasional turut juga diperhatikan dalam pembuatan kontrak tersebut. Diperkenalkan oleh sarjana hukum perdagangan internasional Profesor Aleksancer Goldstajn. Beliau memperkenalkan 3 (tiga) prinsip dasar tersebut, yaitu (1) prinsip kebebasan para pihak dalam berkontrak (the principle of the freedom of contract); (2) prinsip pacta sunt servanda; dan (3) prinsip penggunaan arbitrase. ${ }^{24}$

1. Prinsip Dasar Kebebasan Berkontrak.

Prinsip pertama, kebebasan berkontrak, sebenarnya adalah prinsip universal dalam hukum perdagangan internasional. Setiap sistem hukum pada bidang hukum dagang mengakui kebebasan para pihak ini untuk membuat kontrak-kontrak dagang (internasional):

Schmitthoff menanggapi secara positif kebebasan pertama ini. Beliau menyatakan:

The autonomy of the parties' will in the law of contract is the foundation on which an autonomous law of international trade can be built. The national sovereign

\footnotetext{
${ }^{21}$ Agus Sardjono, Op. Cit, hal. 264-265.

${ }^{22}$ WIPO Secretariat, "Operational Principles for Intellectual Property Clauses of Contractual Agreements Concerning Access to Genetic Resources and Benefit-Sharing”, WIPO/GRTKF/IC/2/3, 10 September 2001, hal. 22-24.

${ }^{23}$ Kitab Undang-Undang Hukum Perdata (Burgelijk Wetboek), Pasal 1332 - 1334.

${ }^{24}$ Aleksander Goldštajn, “The New Law of Merchant,” (1961), JBL 12.
} 
has,..., no objection that in that area an autonomous law of international trade is developed by the parties, provided always that that law respects in every national jurisdiction the limitations imposed by public policy. ${ }^{25}$

Kebebasan tersebut mencakup bidang hukum yang cukup luas. Ia meliputi kebebasan untuk melakukan jenis-jenis kontrak yang para pihak sepakati. Ia termasuk pula kebebasan untuk memilih forum penyelesaian sengketa dagangnya. Ia mencakup pula kebebasan untuk memilih hukum yang akan berlaku terhadap kontrak, dll.

Kebebasan ini sudah barang tentu tidak boleh bertentangan dengan UU, kepentingan umum, kesusilaan, kesopanan, dan lain-lain persyaratan yang ditetapkan oleh masing-masing sistem hukum.

\section{Prinsip Dasar Pacta Sunt Servanda}

Prinsip kedua, pacta sunt servanda adalah prinsip yang mensyaratkan bahwa kesepakatan atau kontrak yang telah ditandatangani harus dilaksanakan dengan sebaik-baiknya (dengan itikad baik). Prinsip ini pun sifatnya universal. Setiap sistem hukum di dunia menghormati prinsip ini

3. Prinsip Dasar Penyelesaian Sengketa Melalui Arbitrase.

Prinsip ketiga, prinsip penggunaan arbitrase tampaknya terdengar agak ganjil. Namun demikian pengakuan Goldštajn menyebut prinsip ini bukan tanpa alasan yang kuat. Arbitrase dalam perdagangan internasional adalah forum penyelesaian sengketa yang semakin umum digunakan. Klausul arbitrase sudah semakin banyak dicantumkan dalam kontrak-kontrak dagang. ${ }^{26}$ Oleh karena itulah prinsip ketiga ini memang relevan.

Goldštajn menguraikan kelebihan dan alasan mengapa penggunaan arbitrase ini beliau jadikan prinsip dasar dalam hukum perdagangan internasional:

Moreover, to the extent that the settlement of differences is referred to arbitration, a uniform legal order is being created. Arbitration tribunals often apply criteria other than those applied in courts.

\footnotetext{
${ }^{25}$ Clive M. Schmitthoff, "Commercial Law in a Changing Economic Climate", (London: Sweet and Maxwell, 1981), hal. 22. (Selanjutnya disebut "Commercial Law").

${ }^{26}$ Rene David, “Arbitration in International Trade”, (The Hague: Kluwer, 1985). Membahas panjang lebar tentang peran arbitrase dalam perdagangan internasional.
} 
Arbitrators appear more ready to interpret rules freely, taking into account customs, usage and business practice. Further, the fact that the enforcement of foreign arbitral awards is generally more easy than the enforcement of foreign court decisions is conducive to a preference for arbitration.

Dari penjabaran yang ada bahwasannya dapat ditarik satu kesimpulan hukum kontrak dengan mengikuti aturan-aturan yang ada maupun prinsip kontrak perdagangan internasional dapat dilaksanakan model hukum kontrak sebagai alternatif benefit sharing oleh pemerintah melalui Direktorat Jendral HKI.

\section{Penutup}

\section{Kesimpulan}

Dari apa yang telah dijabarakan sebelumnya dan terkait permasalahan yang di angkat dalam penulisan karya ilmiah ini maka dengan ini dapat disimpulkan:

1) Bahwasannya pengimplemetasian paten terhadap pengetahuan tradisional tidaklah relevan karenanya pihak-pihak yang ingin memperoleh perlindungan paten harus melakukan langahlangkah tertentu yang membutuhkan keahlian dan kemampuan tertentu pula. Langkah itu dimulai dari penelitian untuk menghasilkan suatu penemuan (invention), penyusunan dokumen paten berupa klain dan spesifikasi paten, pengajuan permohonan perlindungan ke Kantor Paten dan seterusnya sampai dapat hak yang dimaksud. Dan juga rezim HKI lebih mengedepankan hak individual ketimbang hak komunal yang sebagaiman telah dikenal di dalam pengetahuan tradisional

2) Bahwasannya dapat ditarik satu kesimpulan hukum kontrak dengan mengikuti aturan-aturan yang ada maupun prinsip kontrak perdagangan internasional dapat dilaksanakan model hukum kontrak sebagai alternatif benefit sharing oleh pemerintah melalui Direktorat Jendral HKI. Hal ini pula dilihat dari apa yang telah diamanatkan di dalam CBD dan WIPO di dalam profisi WIPO/GRTKF/IC/2/3, 10 September 2001 


\section{Daftar Pustaka}

WIPO Secretariat. Intergovernmental Committee on Intellectual Property and Genetic Resources, Traditional Knowledge and Folklore (IGC),

Center for Inovation Law and Policy, "Traditional Knowledge Reasearch Guide," dalam http://www.innovationlaw.org/lawforum/pages/rg_traditional_knowledge .htm, diakses pada tanggal 23 November 2015.

Patricia A L Cochran, "What is Traditional Knowledge?" http://www.nativescience.org/html/traditional_knowledge.html, diakses pada tanggal 23 November 2015.

WIPO, Intellectual Property, Genetic Resources, Traditional Knowledge, and Folklore http://www.wipo.org/globalissues/tk/back-ground/index.html, diakses pada tanggal 23 November 2015.

United States Patent Office, http://patft.uspto.gov/, di akses pada tangal 23 November 2015.

W.R. Cornish, F.B.A., Intellectual Property: Patents, Copyrights, Trademark and Allied Rights (London: Sweet \& Maxwell, 1989).

Priapantja, Cita Citrawinda, Hak Kekayaan Intelektual: Tantangan Masa Depan, Fakultas Hukum Universitas Indonesia 2003.

M. Sherwood, Robert, Intellectual Property and Economic Development, Boulder, San Fransisco Oxford Westview Press Inc., 1990.

Lawrence M. Friedmen, the legal System A Social Science Perspective, New York: Russel Sage Foundation 1975.

Muhammad, Abdulkadir, Kajian Hukum Ekonomi Hak Kekayaan Intelektual, Bandung: Citra Aditya Bakti, 2001.

Riswandi, Budi Agus, M. Syamsudin, Hak Kekayaan intelektual dan Budaya Hukum, Raja Grafindo Persada, Jakarta.

Sardjono, Agus., Hak Kekayaan Intelektual dan Pengetahuan Tradisional, PT. Alumni, Bandung.

Soyinfo Center, http://www.soyinfocenter.com/HSS/tempeh1.php, diakses pada tanggal 5 Desember 2015.

Rubin , Steven M. \& Stanwood C. Fish, Biodiversity Prospecting:Using Innovative Contractual Provisions to Foster Ethnobotanical Knowledge, Technology, and Conservation, Colorado Journal of International and Environmental Law and Policy, (Vol.5, 1994),

Goldštajn, Aleksander, "The New Law of Merchant," (1961).

Schmitthoff, Clive M., Commercial Law in a Changing Economic Climate, London: Sweet and Maxwell, 1981. 
David, Rene, Arbitration in International Trade, The Hague: Kluwer, 1985. 